\title{
Piezoelectric properties of $\mathrm{Bi}_{2} \mathrm{TeO}_{5}$ single crystals
}

\author{
A.M.Antonenko, K.V.Domoratsky, A.Yu.Kudzin, \\ L.Ya.Sadovskaya \\ Dnipropetrovsk State University, \\ 20 Kazakova Str., 320625 Dnipropetrovsk, Ukraine
}

Received October 12, 1998, in final form October 15, 1999

This paper is devoted to the measurement results of piezoelectric, dielectric and elastic tensor components in the temperature range between $20{ }^{\circ} \mathrm{C}$ and $400{ }^{\circ} \mathrm{C}$. It was revealed that excitation resonance and antiresonance signals were possible without preliminary sample polarizing. Besides, the sound velocities measured along the main axes by echo-pulse method at room temperature are presented.

Key words: piezoelectric, dielectric, elastic constants, sound velocity

PACS: 77.84

Bismuth tellurite (BTO) single crystals are of piezoelectric material but their electromechanical properties have not been practically studied. In [1] there are some data concerning these properties in BTO. The coupling factor $\mathrm{k}_{15}=0.274$ at room temperature presented in the work [2] is prospective enough to be used as the main elements of electromechanical transducers. This fact suggested us to continue studying these properties of $\mathrm{Bi}_{2} \mathrm{TeO}_{5}$. This paper presents the results of investigating the piezoelectric, dielectric and elastic properties of bismuth tellurite single crystals between $20^{\circ} \mathrm{C}$ and $400{ }^{\circ} \mathrm{C}$ (besides the sound velocity vector components which were measured at room temperature). $\mathrm{Bi}_{2} \mathrm{TeO}_{5}$ is a polar single crystal belonging to the Abm2 space group. It possesses the orthorhombic symmetry and the fluorite-type structure with the unit-cell parameters $\mathrm{a}=11.602 \AA, \mathrm{b}=16.461 \AA, \mathrm{c}=5.523 \AA$ $[5]$.

Single crystals of BTO were grown using the Czochralski method. The melt was prepared from ultra high purity $\mathrm{Bi}_{2} \mathrm{O}_{3}$ and $\mathrm{TeO}_{2}$ at the ratio 47 and 53 mole \% respectively just like in the work [4]. The crystal boules were cut along the main crystallographic axes in the form of plates and bars for corresponding coefficients. The cuts in the form of bars were executed in "a"-plane at the angles of $30^{\circ}$ and $45^{\circ}$ to "b"-axis. The sizes of the plates and bars were selected so as to excite the necessary vibrations. The plates were used to obtain $\mathrm{d}_{15}$ and $\mathrm{d}_{24}$ piezoelectric co- 


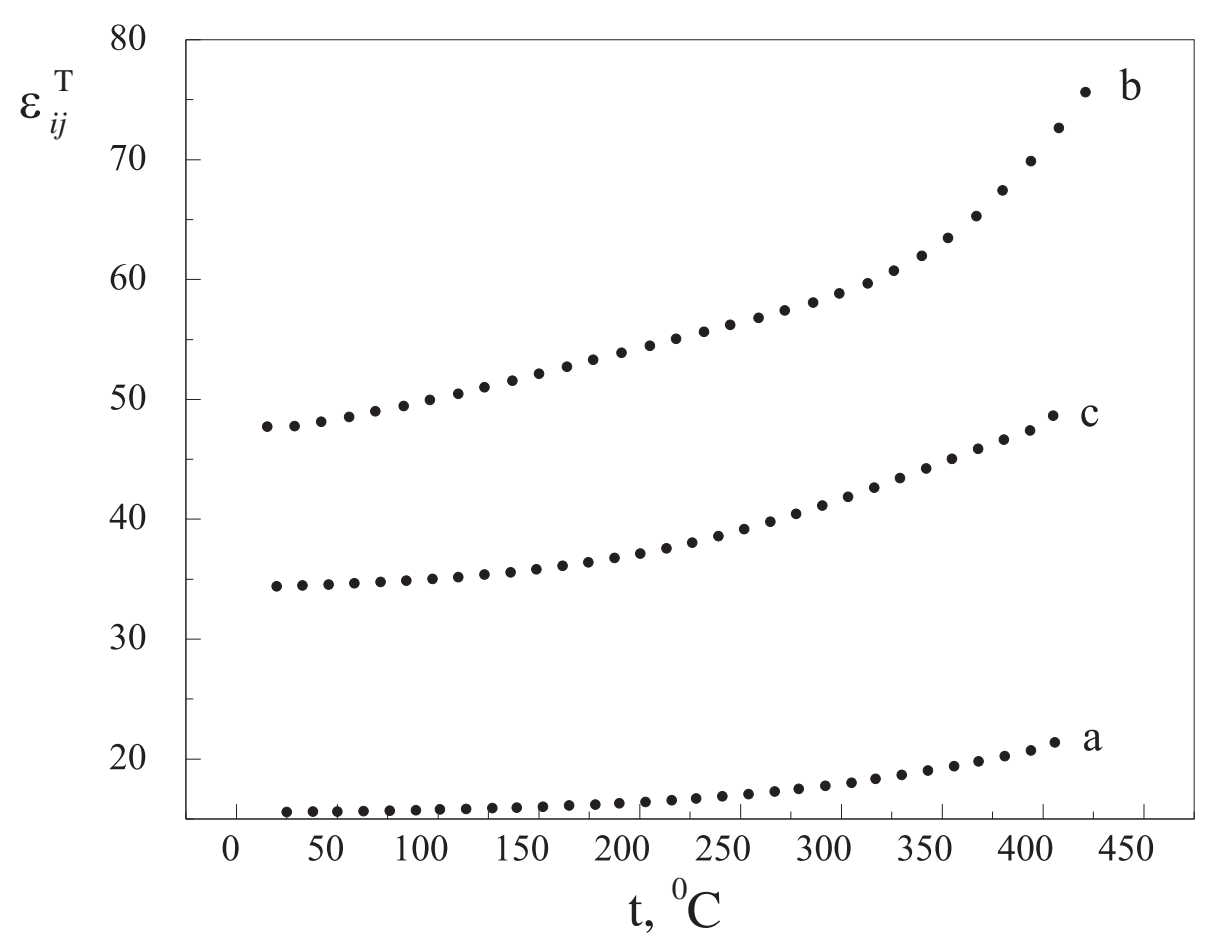

Figure 1. The temperature dependence of BTO dielectric permittivity.

efficient while the other coefficients were obtained on the bars. The sample faces were covered by means of vacuum evaporation of platinum electrodes. For carrying out the sound velocity measurements the crystal boules were cut upon the six plane-parallel specimens so as the work space between the faces was not less than $3 \mathrm{~mm}$. All specimens (three of them were cut along the crystallographic axes and three " $45^{\circ}$ "-cuts to them) after lapping and polishing were used in the experiment.

Measurements of piezoelectric and elastic constants were performed using the resonance-antiresonance techniques in accordance with I.R.E. Standards without preliminary sample polarizing. For a more accurate resonance $\left(\mathrm{f}_{r}\right)$ and antiresonance $\left(\mathrm{f}_{a}\right)$ frequency selection, the sound velocity vector components $\left(v_{i j}\right)(\mathrm{i}, \mathrm{j}=1,2$, 3 ) in the single crystal samples were measured using the echo-pulse method at room temperature. Here $\mathrm{i}$ is the propagation direction and $\mathrm{j}$ is the polarization direction. Measurements of dielectric permittivity were performed using Q-meter at a frequency $100 \mathrm{kHz}$ for all the necessary cuts (X, Y and Z). In figure 1 the temperature dependence of dielectric constants is presented. For all $\epsilon_{i j}^{T}$ components, a weak increase with the temperature rise is observed. As can be seen, a large dielectric permittivity anisotropy is present in the bismuth tellurite.

The elastic and piezoelectric coefficients of bismuth tellurite single crystals in the temperature range of $20-400{ }^{\circ} \mathrm{C}$ are presented in figure 2 . At the temperature increasing the $\mathrm{S}_{11}^{E}, \mathrm{~S}_{22}^{E}, \mathrm{~S}_{44}^{E}$ and $\mathrm{S}_{55}^{E}$ components linearly increase. The temperature coefficients of these constants are $\mathrm{TS}_{55}^{E}=4.810^{-3}, \mathrm{TS}_{55}^{E}=3.310^{-3}, \mathrm{TS}_{44}^{E}=8.810^{-3}$ and $\mathrm{TS}_{55}^{E}=7.910^{-3}$. It can be noticed that the values of elastic constants obtained on the "a" and "b" plates as well as their temperature coefficients are larger than 


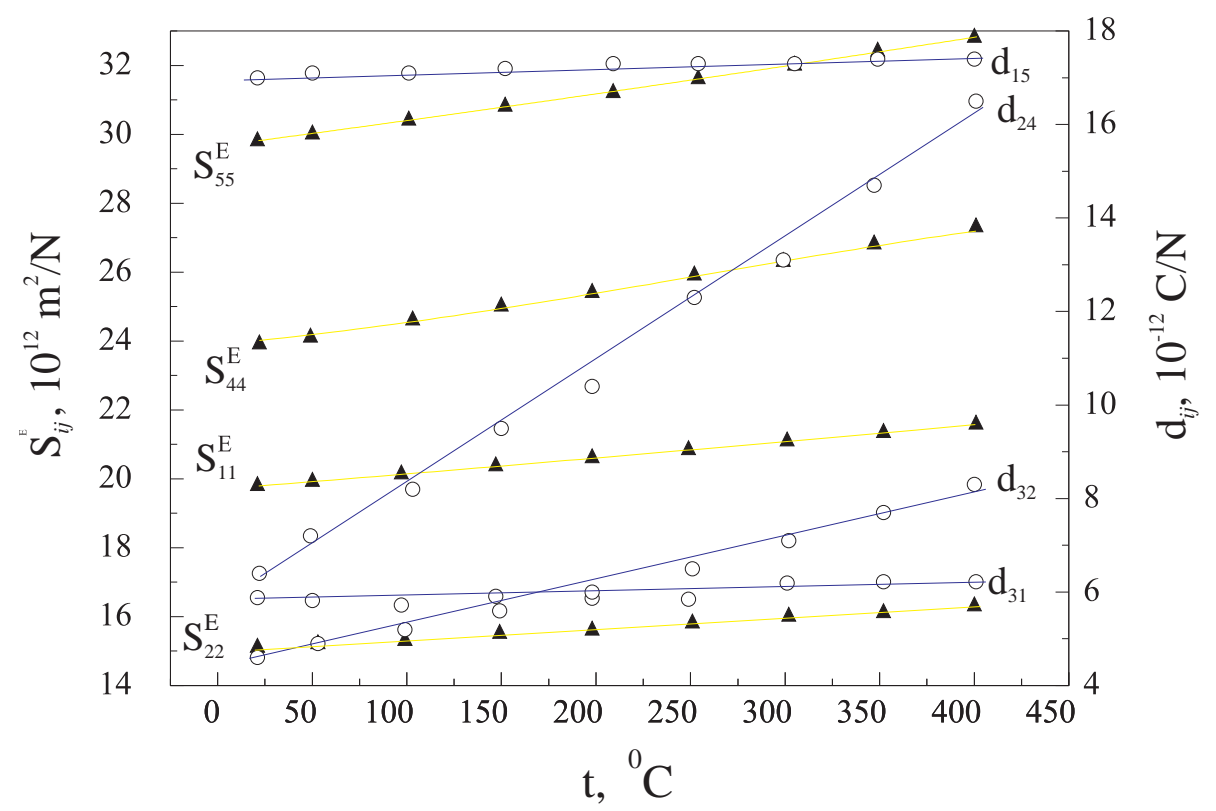

Figure 2. The elastic and piezoelectric constant of bismuth tellurite over the temperature range of $20-400^{\circ} \mathrm{C}$.

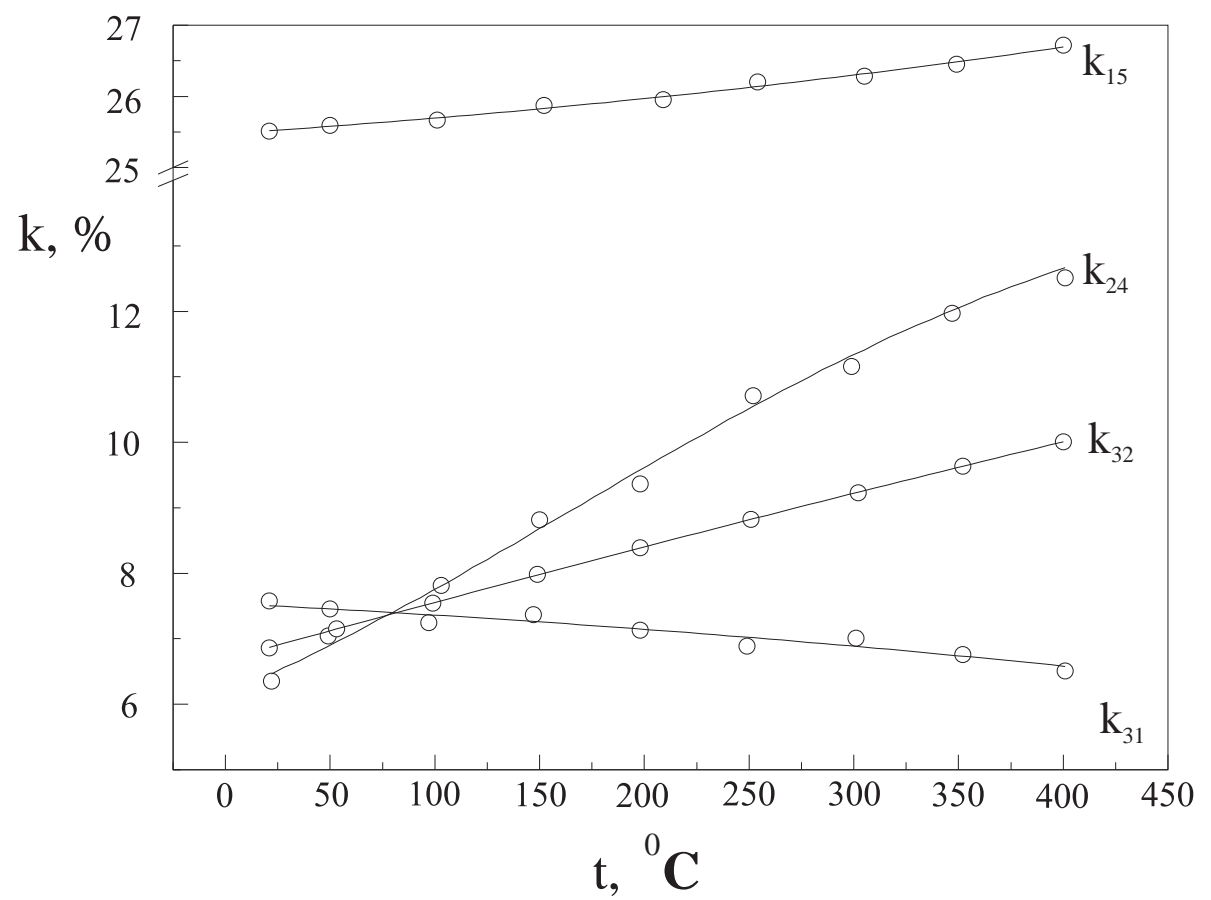

Figure 3. The temperature dependence of BTO electromechanical coupling factors. 
those measured on the bars. The $S_{55}^{E}$ value is the largest and $S_{22}^{E}$ is the smallest of all the elastic constants measured and $S_{33}^{E}$ is the smallest among all longitudinal elastic constants. This component is connected with the polar axis of BTO. Piezoelectric strain coefficients in BTO at the temperature growth linearly increase. The behaviour of all of them is distinguishable. Strong enhancing of $\mathrm{d}_{24}$ is noticed. The temperature dependencies of electromechanical coupling factors are demonstrated in figure 3. These values steadily change at heating.

In the table 1 all the data obtained for BTO samples in this work are allocated. It should be noted that the sound velocity data correlate well with the elastic data presented in the paper [3].

Table 1. Electromechanical properties of BTO at room temperature.

\begin{tabular}{|l|c|}
\hline Parameters & Values \\
\hline$v_{i j}, \mathrm{~m} / \mathrm{s}$ & $v_{11}=3109 \pm 5 ; v_{22}=3264 \pm 1 ; v_{33}=3488 \pm 2 ;$ \\
& $v_{12}=1910 \pm 3 ; v_{13}=1790 \pm 2 ; v_{23}=2106 \pm 2$ \\
\hline$\varepsilon_{i j}^{T}(100 \mathrm{kHz})$ & $\varepsilon_{11}^{T}=16 ; \varepsilon_{22}^{T}=48 ; \varepsilon_{33}^{T}=34$ \\
\hline $\mathrm{S}_{i j}^{E} 10^{-12}, \mathrm{~m}^{2} / \mathrm{N}$ & $\mathrm{S}_{11}^{E}=20 ; \mathrm{S}_{22}^{E}=15 ; \mathrm{S}_{33}^{E}=14 ; \mathrm{S}_{44}^{E}=24 ; \mathrm{S}_{55}^{E}=29 ; \mathrm{S}_{13}^{E}=-4$ \\
\hline $\mathrm{k}_{i j}, \%$ & $\mathrm{k}_{15}=25 ; \mathrm{k}_{24}=6 ; \mathrm{k}_{31}=8 ; \mathrm{k}_{32}=7 ; \mathrm{k}_{33}=11$ \\
\hline $\mathrm{d}_{i j} 10^{-12}, \mathrm{C} / \mathrm{N}$ & $\mathrm{d}_{15}=17 ; \mathrm{d}_{24}=7 ; \mathrm{d}_{31}=6 ; \mathrm{d}_{32}=5 ; \mathrm{d}_{33}=9$ \\
\hline
\end{tabular}

The constant of $\mathrm{d}_{33}$ is the largest coefficient among the other coefficients obtained in the bars. That one corresponds to the polar axis of $\mathrm{Bi}_{2} \mathrm{TeO}_{5}$ single crystal.

The results obtained in this work showed that the material researched has good prospects for a practical use in the field of gcousto-optics and acuosto-electronics.

\section{References}

1. Stefanovich S.Yu., Sadovskaya L.Ya., Antonenko A.M.. Phase transition in bismuth tellurite. // Sol. State Phys. 1991, vol. 37, No. 7, p. 2215-2217 (in Russian).

2. Astafev S.A., Abdulaev A.A., Vorobeva O.I., Dolgih V.A., Popovkin B.A., Silvestrova I.M., Spiridonov E.M. $\mathrm{Bi}_{2} \mathrm{O}_{3 x} \mathrm{TeO}_{2}(\mathrm{x}=1-1.857)$ single crystal growth, some optic, dielectric and acoustic characteristics. // Neorg. Mater., 1991, vol. 27, No. 1, p. 60-63 (in Russian).

3. Antonenko A.M., Gorbenko V.M., Sadovskaya L.Ya., Ermakov S.Yu. Acousto-optic and elastic parameters of bismuth tellurite. // Sol. State Phys. 1996, vol. 38, No. 3, p. 938-941 (in Russian).

4. Domoratsky K.V., Kudzin A.Yu., Sadovskaya L.Ya., Sokolyanskii G.Ch. Doping influence of the physical properties of $\mathrm{Bi}_{2} \mathrm{TeO}_{5}$ single crystals. // Ferroelectrics, 1998, vol. 214, p. 191-197.

5. Mercurio D., El Farissi M., Frit B., Goursat P. Etude structurale et densifi- cation d'un noveaux materiau piezoelectrique $\mathrm{Bi}_{2} \mathrm{TeO}_{5}$. // Mater. Chem. and Phys., 1983, vol. 12, No. 9 , p. $467-476$. 
П'єзоелектричні властивості монокристалів $\mathrm{Bi}_{2} \mathrm{TeO}_{5}$

\author{
А.М.Антоненко, К.В.Доморацький, А.Ю.Кудзін, \\ Л.Я.Садовська \\ Дніпропетровський держуніверситет, фізичний факультет \\ 49625 Дніпропетровськ, пров. Науковий, 13
}

Отримано 12 жовтня 1998 р., в остаточному вигляді 15 жовтня 1999 р.

У роботі наведені результати вимірювань компонент п'єзоелектричних, діелектричних та пружних тензорів у діапазоні температур 20$400^{\circ} \mathrm{C}$. Виявлено, що збудження сигналів резонансу та антирезонансу можливе без попередньої поляризації зразка. Луна-імпульсним методом отримано значення швидкості звуку вздовж головних кристалографічних осей при кімнатній температурі.

Ключові слова: п'єзоелектричні, діелектричні, пружні сталі, швидкість звуку

PACS: 77.84 
